\title{
Antimicrobial Activity of Copper Alone and in Combination with Lactic Acid against Escherichia coli O157:H7 in Laboratory Medium and on the Surface of Lettuce and Tomatoes
}

\author{
Rabin Gyawali, ${ }^{1}$ Salam A. Ibrahim, ${ }^{1}$ Salma H. Abu Hasfa, ${ }^{2}$ \\ Shahnaz Q. Smqadri, ${ }^{3}$ and Yosef Haik ${ }^{3}$ \\ ${ }^{1}$ Food Microbiology and Biotechnology Laboratory, North Carolina Agricultural and Technical State University, 173 Carver Hall, \\ Greensboro, NC 27411, USA \\ ${ }^{2}$ LFRD Department, ALCDR Institute, City of Scientific Research and Technology Applications, P.O. Box 21934, Alexandria, Egypt \\ ${ }^{3}$ Center of Research Excellence in Nanobioscience, The University of North Carolina Greensboro, Greensboro, NC 27412, USA
}

Correspondence should be addressed to Salam A. Ibrahim, ibrah001@ncat.edu

Received 22 June 2011; Accepted 22 August 2011

Academic Editor: Hin-Chung Wong

Copyright () 2011 Rabin Gyawali et al. This is an open access article distributed under the Creative Commons Attribution License, which permits unrestricted use, distribution, and reproduction in any medium, provided the original work is properly cited.

\begin{abstract}
The objective of this study was to evaluate the effect of copper alone and in combination with lactic acid against E. coli O157:H7 in laboratory medium and on the surface of lettuce and tomatoes. Four strains of E. coli O157:H7 were individually inoculated into BHI broth containing different concentrations of copper $(5,10,20$, and $40 \mathrm{ppm}, \mathrm{w} / \mathrm{v})$, lactic acid $(0.1$ and $0.2 \%$, v/v), and their combinations. After incubation, aliquots of $1 \mathrm{~mL}$ from each sample were withdrawn and plated on BHI agar to determine the bacterial population. Significant growth inhibition $(P<0.05)$ was observed with a combination treatment of copper $(40$ ppm) and lactic acid (0.2\%). The population of E. coli O157:H7 was reduced by 3.93 and $3.39 \log$ on the surface of lettuce and tomato samples, respectively, when treated with the same combination. This indicates that combination of copper and lactic acid could be used as an effective solution to inhibit E. coli O157:H7 on fresh produce.
\end{abstract}

\section{Introduction}

Fresh produce is a vital part of the human diet, but concerns about its safety are on the rise. Foodborne illness outbreaks linked to the presence of E. coli O157:H7 in fresh produce have increased over the past few years $[1,2]$. Contaminated fresh produce thus represents the second leading cause of foodborne illnesses in the United States [3]. Different chemical agents (chlorine, hydrogen peroxide, organic acids, ozone, etc.) have been used to decontaminate fresh produce surfaces, but these treatments cannot completely inhibit bacterial pathogens $[4,5]$. Among these treatments, a solution of chlorine is the most common and widely used chemical sanitizer in the fresh produce industry. However, treatment of produce with chlorinated water has a limited bactericidal effect and gives rise to other concerns due to its potential to form carcinogenic by-products [6-8]. Hence, there is a need for safer and more effective antimicrobial treatments for fruits and vegetables.
Consumers are now paying closer attention to the use of artificial chemical preservatives to control foodborne pathogens. The food industry is also looking to use better ingredients as antimicrobial compounds to ensure the safety of food products. Two of the treatments considered in this study are copper and lactic acid. Copper is considered safe to humans as demonstrated inter alia by the use of copper intrauterine devices [9]. It is one of the relatively small groups of metallic elements essential to human health. Copper is required in trace amounts for the growth and functioning of microorganisms; however, higher concentrations can produce a toxic effect [10]. Copper ions have been reported to have antimicrobial activity against a wide range of microorganisms, including Salmonella enterica, Campylobacter jejuni, E. coli, Listeria monocytogenes, and Staphylococcus aureus [11-13]. Metallic copper surfaces have potential application as inhibitory agents in the various stages of food processing operations [11]. Copper has also been shown to inhibit germination, vegetative growth, and 
sporulation of Clostridium tyrobutyricum and has reduced the risk of late blowing spoilage in cheese indicating its potential as a food additive [14]. Lactic acid is generally recognized as safe and is widely used as a biopreservative in naturally fermented products [15]. Lactic acid solutions are one of the most widely applied organic acid treatments used to decontaminate foods. For example, lactic acid has been used successfully to decontaminate meat [16-19]. Lactic acid is therefore considered to have great potential to inactivate microorganisms on the surface of fruits and vegetables.

Although information concerning the use of copper and lactic acid to decontaminate bacterial populations on fresh produce is not available, several studies have shown a synergistic inhibition effect on microbial growth. Copper sulfate $(50 \mathrm{ppm})$ and lactic acid $(150 \mathrm{mM})$ added to liquid pig feed were found to cause a 10 -fold decrease in the Dvalue of Salmonella typhimurium DT104:30 [20]. In another study, a complete elimination of Cronobacter was obtained with a combination of copper $\left(50 \mu \mathrm{g} \mathrm{mL}^{-1}\right)$ and lactic acid $(0.2 \%)$ [21]. In a study using apple cider, a 5-log reduction was achieved for E. coli O157:H7 and Listeria monocytogenes with the combination of copper and sodium hypochlorite following sonication [13]. Similarly, Ibrahim et al. [12] reported a significant growth inhibition of E. coli O157:H7 and Salmonella when both copper (50 ppm) and lactic acid $(0.2 \%)$ were added to laboratory medium and carrot juice.

The mode of action underlying copper and lactic acid antimicrobial effects is not well understood. Studies in the past have proposed several mechanisms to explain the antibacterial activity of copper and lactic acid [22, 23] with regard to morphological changes in bacterial cells. Several techniques have been used to determine the effect of treatments on morphology of the cells. Scanning electron microscopy (SEM) is used for studying microbial colonization and attachments to food or food contact surfaces [24]. SEM is a common technique used to investigate the microorganism cell damage produced by antimicrobial compounds. The outer membrane permeability of Gramnegative bacteria is increased when the cells are exposed to an acidic substance such as lactic acid [25]. Based on this information, we hypothesized that this effect on permeability could enhance the antibacterial efficacy of copper in treating Gram-negative bacteria. The objectives of this study were thus to (i) establish a concentration of copper in combination with lactic acid that effectively inhibits the growth of E. coli O157:H7 in laboratory medium and (ii) determine if such concentration could be used to decontaminate E. coli $\mathrm{O} 157: \mathrm{H} 7$ populations on the surface of lettuce and tomatoes.

\section{Material and Methods}

2.1. Bacterial Strains. The four strains of E. coli O157:H7 (H1730, 43895+, 43895-, and 86.24) used in this study were obtained from the Department of Food Science and Technology at Virginia Polytechnic Institute and State University (Blacksburg, Va, USA). These strains were maintained on tryptic soy agar slants at $4^{\circ} \mathrm{C}$. Strains were then transferred to fresh brain heart infusion broth (BHI; Becton Dicksinson, Sparks, Md, USA) and incubated at $37^{\circ} \mathrm{C}$ for $12 \mathrm{~h}$. Bacterial strains were then streaked onto a BHI agar plate and incubated at $37^{\circ} \mathrm{C}$ for $24 \mathrm{~h}$. Single colonies of each strain were then transferred into $\mathrm{BHI}$ broth and incubated at $37^{\circ} \mathrm{C}$ for $12 \mathrm{~h}$ before use.

2.2. Inoculum Preparation. Each bacterial strain was harvested by centrifugation $\left(8,000 \mathrm{~g}\right.$ for $\left.10 \mathrm{~min}, 4^{\circ} \mathrm{C}\right)$. Cells in pellets were resuspended in $9 \mathrm{~mL}$ of sterile peptone solution $(0.1 \%)$, serially diluted, and $100 \mu \mathrm{L}$ was inoculated into each treatment sample to achieve an initial inoculum level of approximately $3 \log \mathrm{CFU} / \mathrm{mL}$. To determine the effect of copper and lactic acid on the bacterial population on produce surfaces, separate cultures of each individual strain grown in $10 \mathrm{~mL}$ of BHI were mixed together $(40 \mathrm{~mL})$ to produce a four strain mixture of E. coli O157:H7. The cells of this mixture were harvested by centrifugation at $8,000 \mathrm{~g}$ for $15 \mathrm{~min}$ at $4^{\circ} \mathrm{C}$. The supernatant was decanted, and the cell pellet was resuspended in $400 \mathrm{~mL}$ of sterile peptone solution $(0.1 \%, \mathrm{w} / \mathrm{v})$ to give a cell number of approximately $9 \log \mathrm{CFU} / \mathrm{mL}$. Bacterial populations in the inoculum were determined by surface plating duplicate samples on $\mathrm{BHI}$ after serial dilutions in peptone solution $(0.1 \%, \mathrm{w} / \mathrm{v})$. The plates were incubated for $24 \mathrm{~h}$ at $37^{\circ} \mathrm{C}$, and then colonies were counted.

2.3. Media Preparation. Seven $\mathrm{ml}$ batches of fresh $\mathrm{BHI}$ broth containing copper (stock solution of $3.95 \mathrm{~g} \mathrm{CuSO}_{4} \cdot 5 \mathrm{H}_{2} \mathrm{O}$ was prepared by dissolving in $1000 \mathrm{~mL}$ of sterilized distilled water to give $1000 \mathrm{ppm}$ of copper) at concentrations of 5 , 10,20 , and $40 \mathrm{ppm}(\mathrm{w} / \mathrm{v})$, lactic acid at 0.1 and $0.2 \%$, v/v (Thermo Fisher Scientific, Fair Lawn, NJ, USA), and their combination were prepared. An additional $7 \mathrm{~mL}$ of BHI broth not supplemented with any chemical was used as a control. Samples containing control and lactic acid were autoclaved at $121^{\circ} \mathrm{C}$ for $15 \mathrm{~min}$. Copper solution was filter sterilized through $0.2-\mu \mathrm{m}$ Nalgene filtration product (Nalge Nunc International, Rochester, NY, USA) and added to the BHI broth.

2.4. Measuring Bacterial Growth. Bacterial growth was monitored by measuring the turbidity at $8 \mathrm{~h}$ incubation period using a Spectronic 21 Melton Roy spectrophotometer (Thermo Electron Scientific Co., Madission, Wis, USA) at the wavelength of $610 \mathrm{~nm}$. At the end of the incubation $(8 \mathrm{~h})$, one $\mathrm{ml}$ of each treated bacterial suspension was serially $(1: 9)$ diluted in sterile $0.1 \%(\mathrm{w} / \mathrm{v})$ peptone solution and $100 \mu \mathrm{L}$ of appropriated dilution was surface plated on duplicate BHI agar plates. The plates were incubated at $37^{\circ} \mathrm{C}$ for $24 \mathrm{~h}$, and bacterial colonies were counted.

2.5. Determination of $p H$. The $\mathrm{pH}$ values of samples containing copper (20 and $40 \mathrm{ppm}, \mathrm{w} / \mathrm{v})$, lactic acid $(0.2 \% \mathrm{v} / \mathrm{v})$, and their combination were measured. The $\mathrm{pH}$ meter (Accument Excel XL15, Thermo Fisher Scientific, Pittsburgh, Pa, USA) was first calibrated with standard buffers of $\mathrm{pH} 4.0$ and 10.0, and the values were recorded for each sample. 
2.6. Produce Preparation. Romaine lettuce (Lactuca sativa L. var. longifolia) and Roma tomatoes (Lycopersicum esculentum) were purchased at a local grocery store (Greensboro, NC, USA) and stored at $4^{\circ} \mathrm{C}$ the day before testing. Fresh whole tomatoes of similar sizes weighing between 55-65 g each, and without external defects on the skin, were selected and washed with tap water to remove external dirt. Two or three outer leaves of lettuce plant were discarded and a few undamaged inner leaves were selected before the washing procedure. The internal unwilted portions of leaves were cut into pieces of $4 \mathrm{~cm}$ by $4 \mathrm{~cm}$ for inoculation. Tomatoes and pieces of lettuce leaves were then dried at room temperature for $1 \mathrm{~h}$ in the biosafety cabinet (Labanco Corporation Kansas City, MO, USA) to remove moisture from the surface.

2.7. Produce Inoculation. Whole tomatoes and pieces $(4 \times$ $4 \mathrm{~cm}$ ) of lettuce leaves were then submerged into $400 \mathrm{~mL}$ of inoculum mixture $(\sim 9 \log \mathrm{CFU} / \mathrm{mL})$, prepared as described earlier, and gently agitated by hand with a stainless steel spoon for $2 \mathrm{~min}$ at room temperature $\left(22^{\circ} \mathrm{C}\right)$ to ensure uniform inoculation. Each produce type was inoculated separately in $400 \mathrm{~mL}$ of inoculum in $1000-\mathrm{mL}$ beakers. To increase the number of cells attached, the samples were kept at $4^{\circ} \mathrm{C}$ for $12 \mathrm{~h}$ in sterile bags. All produce was then air dried in a laminar flow hood, on a sterile petri dish, for $1 \mathrm{~h}$ at room temperature, to facilitate bacterial adhesion before treatment.

2.8. Preparation of Treatment Solutions. Fresh solutions of copper and lactic acid were prepared the same day as each experiment. Copper stock solution of $1000 \mathrm{ppm}$ was prepared ( $3.93 \mathrm{~g} \mathrm{CuSO}_{4} \cdot 5 \mathrm{H}_{2} \mathrm{O}$ per liter) and filter sterilized through a $0.2-\mu \mathrm{m}$ Nalgene filteration product. The appropriate volume was then added to the treatment solution to give final concentrations of 20 and $40 \mathrm{ppm}$ copper. A solution containing copper (20 and $40 \mathrm{ppm})$, lactic acid $(0.2 \%)$, and their combination $(20 \mathrm{ppm} \mathrm{Cu}+0.2 \% \mathrm{La}$ and $40 \mathrm{ppm} \mathrm{Cu}+$ $0.2 \% \mathrm{La}$ ) with and without $0.1 \% \mathrm{v} / \mathrm{v}$ Tween 80 (Fisher Scientific, Fair Lawn, NJ, USA) and Tween 80 only were prepared in deionized water. All solutions without copper were sterilized at $121^{\circ} \mathrm{C}$ for $15 \mathrm{~min}$.

2.9. Rinse Treatment. The washing method described by Lang et al. [26] and Velázquez et al. [2] was used in this study with slight modification. After air drying, 12 pieces of lettuce leaves and 12 whole tomatoes were individually placed inside sterile plastic bags and then rinsed with $10 \mathrm{~mL}$ of each treatment. Treatments included $20 \mathrm{ppm}$ copper, $40 \mathrm{ppm}$ copper, $0.2 \%$ lactic acid, $0.1 \%$ Tween 80 , and combination of copper and lactic acid with and without Tween 80 . The bags were gently shaken, and each tomato was hand rubbed for 1 min to facilitate wetting by the treatment solution. Bags with lettuce leaves were also hand agitated for one min and shaken at $100 \mathrm{rpm}$ (Orbit shaker, Lab-Line instruments, Inc. Melrose Park, Ill, USA) for $3 \mathrm{~min}$. Two bags containing inoculated samples of lettuce and tomato without any treatment were considered as control samples. After washing, each sample (treated and control) was then transferred to a new sterile bag and subjected to a $10 \mathrm{~mL}$ of $0.1 \%$ peptone solution and agitated for $1 \mathrm{~min}$ to release bacteria $[2,26]$.

2.10. Microbiological Analysis. One $\mathrm{ml}$ of wash suspension from each bag was serially diluted with $9 \mathrm{~mL}$ of sterile $0.1 \%$ peptone solution, and $100 \mu \mathrm{L}$ of appropriate dilution was plated on duplicate BHI agar. The plates were incubated at $37^{\circ} \mathrm{C}$ for $24 \mathrm{~h}$, and bacterial colonies were counted. Typical creamy whitish colonies characteristic of E. coli O157:H7 were only counted. Bacterial populations were reported as $\log$ CFU/lettuce leaf or log CFU/tomato [2].

2.11. Scanning Electron Microscopy (SEM). The morphological changes of bacterial cells treated with or without copper/lactic acid were investigated using SEM. Bacterial cells were washed with phosphate-buffered saline (PBS; $50 \mathrm{mM}, \mathrm{pH} 7.4$ ), fixed with $5 \%$ glutaraldehyde at $4^{\circ} \mathrm{C}$ for $2 \mathrm{~h}$, then washed in the buffered solution to remove the glutaraldehyde. Next, samples were dehydrated with a series of ethanol solutions $(50 \%, 70 \%, 80 \%, 90 \%$, and $100 \%)$ with $10 \mathrm{~min}$ of exposure per concentration. The dehydrated samples were dried immediately, and mounted on SEM stubs and sputter coated (Pello model 3, Sputter coater 91000, Ted Pella Inc., NY, USA) with a thin layer of gold. The coated samples were observed under SEM (Hitachi S4800, Hitachi Ltd, Tokyo, Japan) at a voltage of $15 \mathrm{kV}$.

2.12. Statistical Analysis. Different treatments were statistically analyzed for their effects on E. coli $\mathrm{O} 157: \mathrm{H} 7$ by a factorial analysis of variance of duplicate samples. Each experiment was replicated three times to determine the effect of copper alone and in combination with lactic acid on the survival and growth of the bacteria. Data were analyzed using the general linear models procedure of the Statistical Analysis Software (SAS Institute, Cary, NC, USA) with the use of Duncan's multiple range to determine significant differences among the treatments $(P<0.05)$.

\section{Results}

3.1. Study in Laboratory Medium. Table 1 shows the effects of copper alone or in combination with lactic acid on the growth of E. coli O157:H7 strains in BHI broth samples. When E. coli O157:H7 strains were grown in BHI broth alone (control samples), the bacterial strains continued to grow from initial turbidity $(\sim 0.03$, O.D. $610 \mathrm{~nm})$ and reached maximum absorbance of $0.78-0.84$ within $8 \mathrm{~h}$ of incubation at $37^{\circ} \mathrm{C}$. When copper was added at $5 \mathrm{ppm}$ and $10 \mathrm{ppm}$, a slight inhibition was observed as measured by turbidity (0.76-0.82). Further addition of $20 \mathrm{ppm}$ and $40 \mathrm{ppm}$ copper also showed slight growth inhibition (O.D. 0.65-0.78). This indicated that the presence of copper alone had a slight effect on the growth inhibition of E. coli O157:H7. When lactic acid was added to BHI broth at $0.1 \%$ or $0.2 \%$ lactic acid, slight growth inhibition was observed. The addition of $5 \mathrm{ppm}$ or $10 \mathrm{ppm}$ copper in combination with $0.1 \%$ and $0.2 \%$ lactic acid did not show additional growth inhibition. However, when copper was added (20 ppm or $40 \mathrm{ppm}$ ) in 
TABLE 1: Growth of E. coli O157:H7 strains in BHI broth (O.D.) after incubation for $8 \mathrm{~h}$ at $37^{\circ} \mathrm{C}$ in the presence of $(\mathrm{Cu})$ and lactic acid (La).

\begin{tabular}{|c|c|c|c|c|}
\hline \multicolumn{5}{|c|}{ E. coli O157:H7 strains } \\
\hline Treatments & H1730 & $43895+$ & $43895-$ & 86.24 \\
\hline \multicolumn{5}{|c|}{ O.D. $610 \mathrm{~nm}$} \\
\hline Control & $0.84^{\mathrm{a}} \pm 0.064$ & $0.81^{\mathrm{a}} \pm 0.014$ & $0.78^{\mathrm{a}} \pm 0.035$ & $0.83^{\mathrm{a}} \pm 0.021$ \\
\hline $\mathrm{Cu} 5 \mathrm{ppm}$ & $0.81^{\mathrm{ab}} \pm 0.035$ & $0.78^{\mathrm{ab}} \pm 0.007$ & $0.77^{\mathrm{ab}} \pm 0.021$ & $0.82^{\mathrm{ab}} \pm 0.042$ \\
\hline $\mathrm{Cu} 10$ ppm & $0.80^{\mathrm{ab}} \pm 0.014$ & $0.76^{\mathrm{bc}} \pm 0.014$ & $0.77^{\mathrm{ab}} \pm 0.007$ & $0.79^{b c} \pm 0.028$ \\
\hline $\mathrm{Cu} 20$ ppm & $0.78^{\mathrm{b}} \pm 0.028$ & $0.74^{\mathrm{bc}} \pm 0.014$ & $0.74^{\mathrm{ac}} \pm 0.014$ & $0.75^{\mathrm{cd}} \pm 0.014$ \\
\hline $\mathrm{Cu} 40$ ppm & $0.76^{\mathrm{bc}} \pm 0.014$ & $0.71^{\mathrm{de}} \pm 0.042$ & $0.65^{\mathrm{d}} \pm 0.007$ & $0.69^{\mathrm{ef}} \pm 0.007$ \\
\hline La $0.1 \%$ & $0.71^{\mathrm{cd}} \pm 0.028$ & $0.69^{\mathrm{e}} \pm 0.021$ & $0.71^{\mathrm{c}} \pm 0.049$ & $0.72^{\text {de }} \pm 0.014$ \\
\hline $\mathrm{La} 0.1 \%+\mathrm{Cu} 5$ ppm & $0.70^{\mathrm{cd}} \pm 0.014$ & $0.67^{\mathrm{ef}} \pm 0.021$ & $0.71^{\mathrm{c}} \pm 0.021$ & $0.69^{\mathrm{ef}} \pm 0.049$ \\
\hline $\mathrm{La} 0.1 \%+\mathrm{Cu} 10 \mathrm{ppm}$ & $0.66^{\text {ed }} \pm 0.007$ & $0.65^{\mathrm{f}} \pm 0.014$ & $0.71^{c} \pm 0.007$ & $0.69^{\mathrm{ef}} \pm 0.000$ \\
\hline $\mathrm{La} 0.1 \%+\mathrm{Cu} 20 \mathrm{ppm}$ & $0.63^{\mathrm{ef}} \pm 0.000$ & $0.61^{\mathrm{g}} \pm 0.021$ & $0.65^{d} \pm 0.014$ & $0.66^{\mathrm{f}} \pm 0.028$ \\
\hline $\mathrm{La} 0.1 \%+\mathrm{Cu} 40 \mathrm{ppm}$ & $0.61^{\mathrm{efg}} \pm 0.028$ & $0.55^{\mathrm{h}} \pm 0.021$ & $0.51^{\mathrm{ef}} \pm 0.021$ & $0.58^{\mathrm{g}} \pm 0.007$ \\
\hline La $0.2 \%$ & $0.58^{\mathrm{fg}} \pm 0.021$ & $0.50^{\mathrm{i}} \pm 0.007$ & $0.54^{\mathrm{e}} \pm 0.007$ & $0.60^{\mathrm{g}} \pm 0.000$ \\
\hline $\mathrm{La} 0.2 \%+\mathrm{Cu} 5 \mathrm{ppm}$ & $0.55^{\mathrm{g}} \pm 0.071$ & $0.49^{\mathrm{i}} \pm 0.014$ & $0.48^{\mathrm{f}} \pm 0.021$ & $0.52^{\mathrm{h}} \pm 0.000$ \\
\hline $\mathrm{La} 0.2 \%+\mathrm{Cu} 10 \mathrm{ppm}$ & $0.48^{\mathrm{h}} \pm 0.014$ & $0.44^{j} \pm 0.007$ & $0.38^{\mathrm{g}} \pm 0.007$ & $0.50^{\mathrm{h}} \pm 0.007$ \\
\hline $\mathrm{La} 0.2 \%+\mathrm{Cu} 20 \mathrm{ppm}$ & $0.28^{\mathrm{i}} \pm 0.028$ & $0.35^{\mathrm{k}} \pm 0.014$ & $0.28^{\mathrm{h}} \pm 0.007$ & $0.36^{\mathrm{i}} \pm 0.028$ \\
\hline $\mathrm{La} 0.2 \%+\mathrm{Cu} 40 \mathrm{ppm}$ & $0.11^{\mathrm{j}} \pm 0.028$ & $0.26^{1} \pm 0.021$ & $0.17^{\mathrm{a}} \pm 0.007$ & $0.26^{j} \pm 0.021$ \\
\hline
\end{tabular}

Means ( \pm standard deviation) within the same column not followed by the same letters are significantly different $(P<0.05)$.

Initial bacterial population was approximately $3.00 \log \mathrm{CFU} / \mathrm{mL}$.

combination with $0.1 \%$ and $0.2 \%$ lactic acid, a significant growth inhibition was observed. Addition of copper at 20 and $40 \mathrm{ppm}$ with $0.2 \%$ lactic acid caused higher growth inhibition of the tested strains $(P<0.05)$ when compared with control or individually treated samples. The $\mathrm{pH}$ values of the BHI broth samples treated with $20 \mathrm{ppm}$ and $40 \mathrm{ppm}$ copper in combination with $0.2 \%$ lactic acid were 5.69 and 5.48, respectively, indicating that acid is not the main inhibiting factor in this study.

Table 2 shows the populations of E. coli O157:H7 strains $(\log \mathrm{CFU} / \mathrm{mL})$ grown in BHI broth containing different concentrations of copper and lactic acid, alone or in combination, during incubation at $37^{\circ} \mathrm{C}$ for $8 \mathrm{~h}$. In the control samples, the numbers of $E$. coli strains increased from an initial population of $3 \log \mathrm{CFU} / \mathrm{mL}$ and reached an average of $9.93 \log \mathrm{CFU} / \mathrm{mL}$. With the addition of copper at different concentrations, the growth of E. coli O157:H7 was not significantly inhibited $(P>0.05)$. Therefore, copper alone did not significantly inhibit the tested strains. Growth in $\mathrm{BHI}$ broth containing $0.1 \%$ lactic acid was not significantly affected compared to growth in the control or BHI containing only copper. When E. coli O157:H7 was grown in BHI broth containing four different concentrations of copper and in combination with $0.1 \%$ lactic acid, the growth of bacterial populations were slightly inhibited compared to the control and copper alone samples. Maximum of $1.09 \mathrm{log}$ reduction was achieved when 40 ppm copper was supplemented with $0.1 \%$ lactic acid when compared to the lactic acid only sample. When E. coli O157:H7 was grown in BHI broth containing $0.2 \%$ lactic acid alone, or in combination with 5 and $10 \mathrm{ppm}$ copper, reductions in the bacterial population of 2.91, 3.59 and $3.73 \log \mathrm{CFU} / \mathrm{mL}$ compared to the control were not significantly different from each other. However, when a combination of 20 ppm copper with $0.2 \%$ lactic acid was used, $4.37 \log \mathrm{CFU} / \mathrm{mL}$ reduction in bacterial population was achieved compared to the control sample. Furthermore, with the addition of $40 \mathrm{ppm}$ copper to $0.2 \%$ lactic acid, the bacterial population was reduced by $5.03 \log \mathrm{CFU} / \mathrm{mL}$ compared to the control $(9.93 \log \mathrm{CFU} / \mathrm{mL})$. Therefore, 20 and $40 \mathrm{ppm}$ of copper in combination with $0.2 \%$ of lactic acid is the most effective treatment to inhibit the growth of E. coli O157:H7 in BHI media.

3.2. Effect on Produce Surface. Figures 1(a) and 1(b) show the populations of E. coli O157:H7 on the surface of lettuce and tomatoes samples treated with copper alone or in combination with lactic acid solution. The initial inoculum concentration of mixed strains of E. coli O157:H7 was approximately $9 \log \mathrm{CFU} / \mathrm{mL}$. The microbial population in untreated samples (control) was $8.31 \mathrm{CFU} /$ lettuce piece and 7.01 CFU/tomato. Rinsing lettuce pieces and whole tomatoes with copper $20 \mathrm{ppm}$ solution alone resulted in $0.66 \mathrm{log}$ and $0.07 \log$ reductions of E. coli O157:H7, respectively, while treatment with $40 \mathrm{ppm}$ copper resulted in $1.12 \mathrm{log}$ and $0.13 \log$ reductions on lettuce and tomato surfaces, respectively. Samples when rinsed with $0.2 \%$ lactic acid slightly reduced the number of microbial populations on both lettuce and tomato surfaces than the control samples. When food samples were rinsed with a combination of $20 \mathrm{ppm}$ copper and $0.2 \%$ lactic acid, 2.89 log and $2.2 \mathrm{log}$ reductions were achieved per lettuce piece and tomato, respectively. However, with the treatment of $40 \mathrm{ppm}$ copper and $0.2 \%$ lactic acid, 3.23 and $2.29 \log$ reductions of E. coli O157:H7 were achieved from lettuce and tomato surfaces, respectively. Our results demonstrated that the addition of 
TABle 2: Populations of E. coli O157:H7 strains grown in BHI broth (Log CFU/mL) containing different concentrations of copper (Cu) and lactic acid (La) after incubation for $8 \mathrm{~h}$ at $37^{\circ} \mathrm{C}$.

\begin{tabular}{|c|c|c|c|c|c|}
\hline \multicolumn{6}{|c|}{ E. coli O157:H7 strains } \\
\hline Treatments & H1730 & $43895+$ & $43895-$ & 86.24 & Average \\
\hline \multicolumn{6}{|c|}{$\log \mathrm{CFU} / \mathrm{mL}$} \\
\hline Control & 10.42 & 10.40 & 9.37 & 9.55 & $9.93^{\mathrm{a}} \pm 0.55$ \\
\hline $\mathrm{Cu} 5 \mathrm{ppm}$ & 10.28 & 10.35 & 9.34 & 9.45 & $9.85^{\mathrm{a}} \pm 0.53$ \\
\hline $\mathrm{Cu} 10 \mathrm{ppm}$ & 10.25 & 10.12 & 9.29 & 9.42 & $9.77^{\mathrm{a}} \pm 0.48$ \\
\hline $\mathrm{Cu} 20$ ppm & 9.70 & 9.20 & 9.08 & 9.25 & $9.30^{\mathrm{ab}} \pm 0.27$ \\
\hline $\mathrm{Cu} 40 \mathrm{ppm}$ & 9.51 & 9.17 & 8.98 & 9.10 & $9.19^{\mathrm{ab}} \pm 0.22$ \\
\hline La $0.1 \%$ & 9.45 & 9.68 & 8.75 & 8.45 & $9.08^{\mathrm{abc}} \pm 0.56$ \\
\hline $\mathrm{La} 0.1 \%+\mathrm{Cu} 5 \mathrm{ppm}$ & 9.40 & 9.55 & 7.86 & 7.60 & $8.60^{\mathrm{bc}} \pm 1.02$ \\
\hline $\mathrm{La} 0.1 \%+\mathrm{Cu} 10 \mathrm{ppm}$ & 9.31 & 9.25 & 7.82 & 7.30 & $8.42^{\mathrm{bc}} \pm 1.01$ \\
\hline $\mathrm{La} 0.1 \%+\mathrm{Cu} 20 \mathrm{ppm}$ & 9.15 & 8.93 & 7.72 & 6.95 & $8.18^{b c} \pm 1.03$ \\
\hline $\mathrm{La} 0.1 \%+\mathrm{Cu} 40 \mathrm{ppm}$ & 9.10 & 8.34 & 7.66 & 6.87 & $7.99^{\mathrm{cd}} \pm 0.95$ \\
\hline La $0.2 \%$ & 7.81 & 7.30 & 6.15 & 6.84 & $7.02^{\text {de }} \pm 0.70$ \\
\hline $\mathrm{La} 0.2 \%+\mathrm{Cu} 5 \mathrm{ppm}$ & 7.49 & 6.90 & 5.95 & 5.02 & $6.34^{\mathrm{ef}} \pm 1.08$ \\
\hline $\mathrm{La} 0.2 \%+\mathrm{Cu} 10 \mathrm{ppm}$ & 7.11 & 6.82 & 5.90 & 5.00 & $6.20^{\mathrm{ef}} \pm 0.95$ \\
\hline $\mathrm{La} 0.2 \%+\mathrm{Cu} 20 \mathrm{ppm}$ & 6.03 & 6.02 & 5.55 & 4.66 & $5.56^{\mathrm{fg}} \pm 0.64$ \\
\hline $\mathrm{La} 0.2 \%+\mathrm{Cu} 40 \mathrm{ppm}$ & 5.46 & 5.51 & 4.56 & 4.10 & $4.90^{\mathrm{gh}} \pm 0.69$ \\
\hline
\end{tabular}

Means ( \pm standard deviation) within the same column not followed by same letters are significantly different $(P<0.05)$.

Initial bacterial population was approximately $3.00 \log \mathrm{CFU} / \mathrm{mL}$.

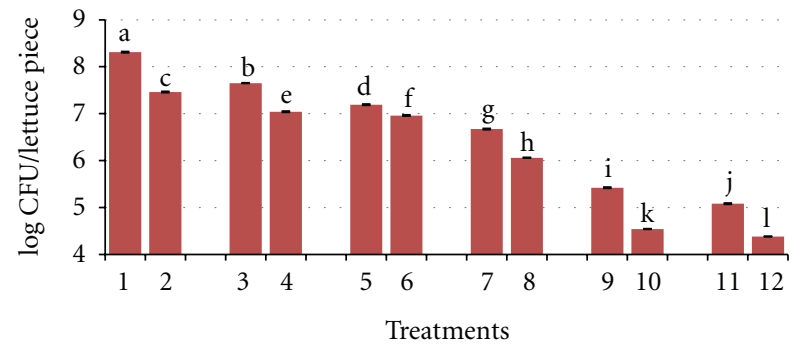

(a)

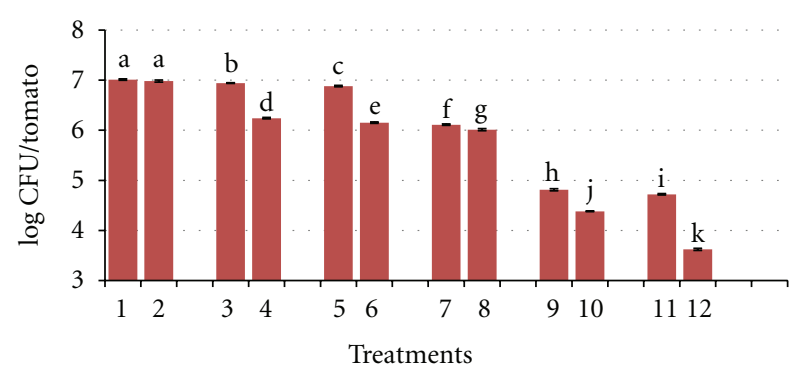

(b)

Figure 1: Populations of E. coli O157:H7 on the surface of (a) lettuce and (b) tomato samples treated with copper $(\mathrm{Cu})$ and lactic acid (La) solution with and without Tween 80 (T80) as surfactant. The error bars represent the standard deviations for replicate samples. Means with different letters over the error bars are significantly different $(P<0.05)$. (1) Control, (2) Tween $80,(3)$ $\mathrm{Cu} 20$ ppm, (4) Cu 20 ppm + T80, (5) Cu 40 ppm, (6) Cu 40 ppm + T80, (7) La $0.2 \%$, (8) La 0.2\% + T80, (9) La $0.2 \%+$ Cu 20 ppm, (10) $\mathrm{La} 0.2 \%+\mathrm{Cu} 20 \mathrm{ppm}+\mathrm{T} 80$, (11) La $0.2 \%+\mathrm{Cu} 40 \mathrm{ppm}$, and (12) $\mathrm{La} 0.2 \%+\mathrm{Cu} 40 \mathrm{ppm}+\mathrm{T} 80$. treatment with $40 \mathrm{ppm}$ copper in combination with $0.2 \%$ lactic acid significantly $(P<0.05)$ reduces the bacterial population on the surface of contaminated produce.

We also observed the impact of copper in combination with lactic acid and Tween 80 as surfactant. There was less than $1 \log$ reduction when the lettuce surface was treated with $0.1 \%$ Tween 80 alone, and there was no significant difference between the treated tomato surface and untreated sample. Lettuce treated with copper 20 and $40 \mathrm{ppm}$ with Tween 80 , produced more than $1 \log$ reduction. However, less than $1 \log$ reduction was achieved from tomato surfaces than from lettuce undergoing the same treatment. With the addition of lactic acid $(0.2 \%)$ to Tween $80(0.1 \%)$, reductions of $2.25 \log \mathrm{CFU} /$ lettuce piece and $1 \log \mathrm{CFU} /$ tomato were observed. Similarly, less than $1 \log$ bacterial populations were achieved from both lettuce and tomato samples rinsed with the individual treatments of copper and lactic acid in the presence of Tween 80 as compared with individual treatments without Tween 80 . Lettuce and tomato treated with $20 \mathrm{ppm}$ copper and $0.2 \%$ lactic acid, plus $0.1 \%$ Tween 80 , reduced bacterial populations by $3.77 \log$ and $2.63 \mathrm{log}$, respectively. When samples were treated with a $40 \mathrm{ppm}$ copper and both $0.2 \%$ lactic acid and Tween 80 , higher microbial reductions on both produce surfaces were achieved. The populations on lettuce and tomato surfaces were reduced by $3.93 \log \mathrm{CFU} / \mathrm{lettuce}$ piece and $3.39 \log \mathrm{CFU} /$ tomato, respectively.

\section{Bacterial Morphology}

Figure 2 shows the impact of copper alone or in combination with lactic acid on the morphology of E. coli O157:H7 using 


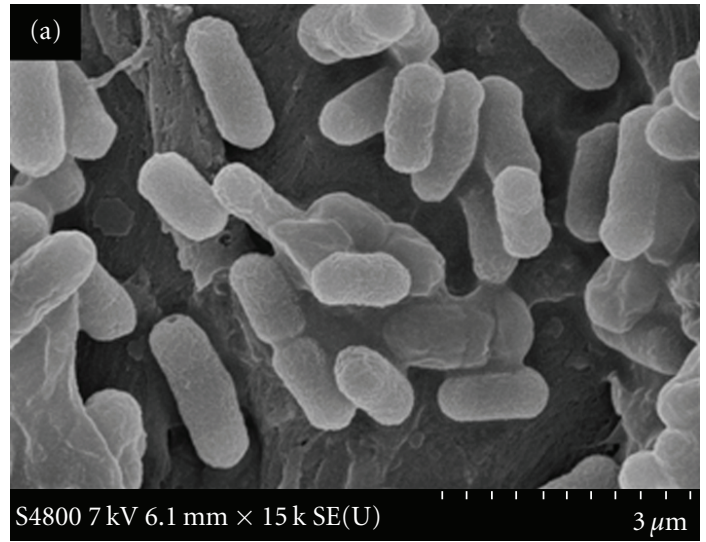

(a)

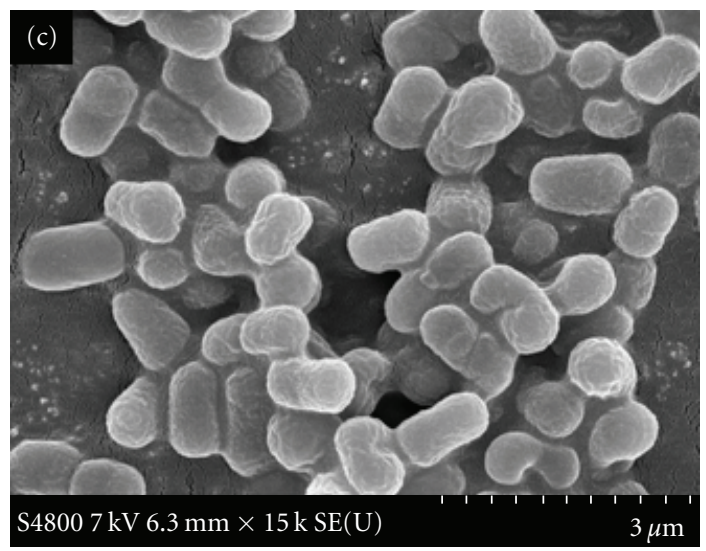

(c)

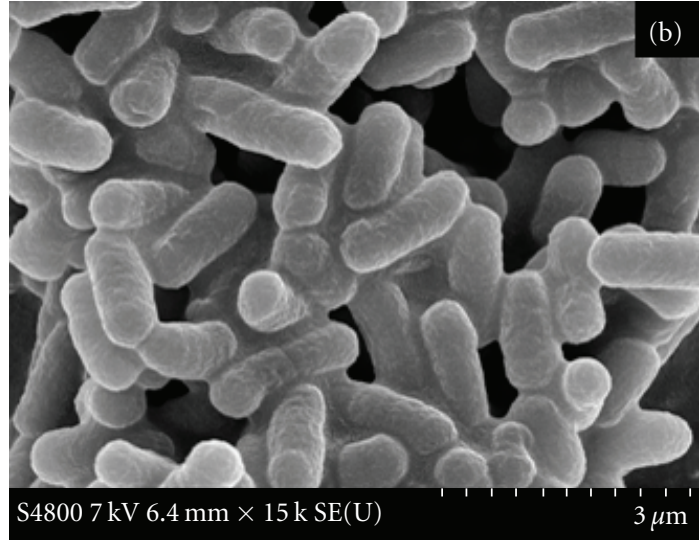

(b)

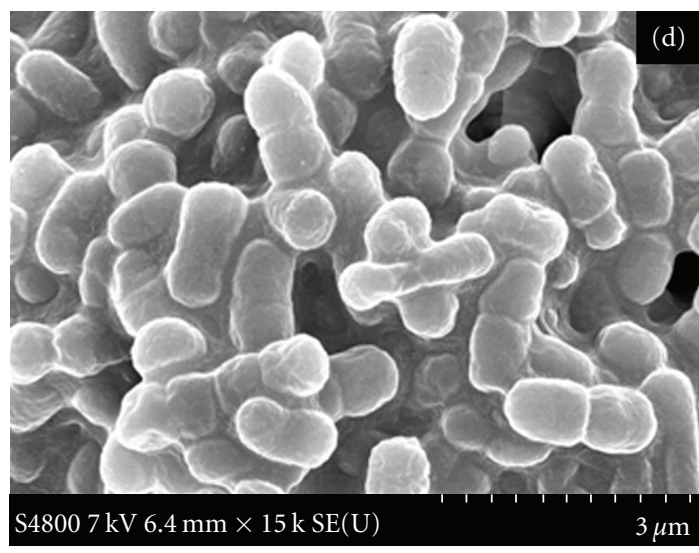

(d)

FIGURE 2: Effect of lactic acid and copper on the morphology of E. coli O157:H7 as demonstrated by scanning electron microscopy: (a) control, (b) lactic acid, (c) copper, and (d) lactic acid and copper.

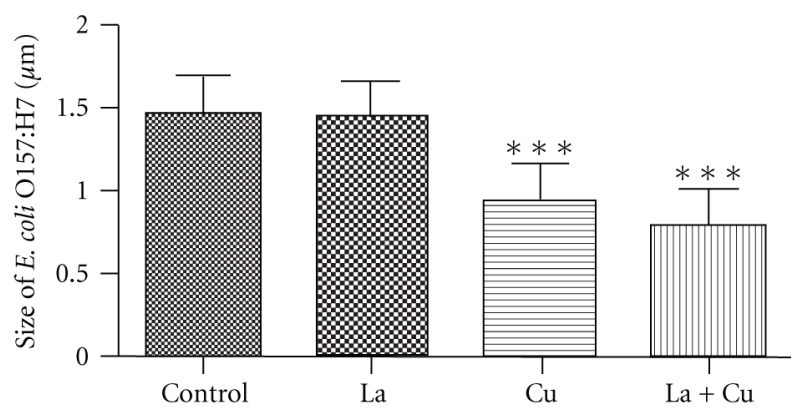

Each bar $= \pm$ Mean

$* * *=P$ value $\leq 0.001$

Figure 3: Histogram showing size $(\mu \mathrm{m})$ of E. coli O157:H7 after treated with copper and lactic acid.

SEM. The bacterial cells (E. coli O157:H7) in the control samples (without treatment) (Figure 2(a)) showed a normal rod shape with smooth surface. Morphological (shape, size, and appearance) changes in bacterial cells were not different when treated with lactic acid (Figure 2b). On the contrary, cells grown in copper alone or in combination with lactic acid (Figures 2(c) and 2(d)) were more abnormal in shape and size indicating a disruption of the membrane integrity. In fact, the morphology of these cells (Figures 2(c) and 2(d)) revealed wrinkled abnormalities with numerous small clefts distributed around the cell surfaces. Figure 3 shows the size distribution histogram of treated and untreated cells. The average size of untreated cells (control) and cells treated with lactic acid were not found to be different. On the other hand, cells treated with copper alone or in combination with lactic acid showed a significant difference $(P<0.001)$ in their sizes. The average cell size reduced from $1.44 \mu \mathrm{m}$ (control) to $0.81 \mu \mathrm{m}$ when treated with copper in combination with lactic acid.

\section{Discussion}

Previous studies showed that E. coli O157:H7 was implicated in several outbreaks involving acidic fruits and fruit juices at $\mathrm{pH}$ value of $3.4[27,28]$. E. coli $\mathrm{O} 157: \mathrm{H} 7$ has also survived well in beef slurries with lactic acid [29], raising concern about the tolerance of E. coli O157:H7 to low pH. Therefore, 
it is very important to control the growth of these pathogens. Our work demonstrated that treatment with copper in combination with lactic acid showed a synergistic effect against E. coli $\mathrm{O} 157: \mathrm{H} 7$. Similar results were also obtained with $E$. coli $\mathrm{O} 157: \mathrm{H7}$ in BHI broth and carrot juice in the presence of copper $(50 \mathrm{ppm})$ and lactic acid $(0.2 \%)$, indicating a significant inhibitory effect of copper and lactic acid [12]. Based on the results obtained from these two studies in laboratory medium, $40 \mathrm{ppm}$ copper and $0.2 \%$ lactic acid could be used as a potential sanitizer to decontaminate produce surfaces. It has been demonstrated previously that the efficacy of copper ion in killing microorganisms is greatly enhanced by the use of lactic acid. Hence, the use of copper in combination with lactic acid might be an effective method to inhibit pathogenic bacteria from the surfaces of produce. Therefore, $20 \mathrm{ppm}$ or $40 \mathrm{ppm}$ copper in combination with $0.2 \%$ lactic acid could be used to control the growth of $E$. coli O157:H7.

Results showed that the treatment with Tween 80 alone or in combination with copper or lactic acid alone did not effectively reduce the bacterial reductions from the produce surfaces. However, a combination of copper and lactic acid plus Tween 80 effectively reduced populations of $E$. coli O157:H7 on the produce samples. Even though washing with chlorinated water is the most widely used method to inactivate pathogenic bacteria on the surfaces of fresh produce, the efficacy of chlorinated water is minimal and can only achieve approximately 2 to $3 \mathrm{log}$ reductions of native microflora [30, 31]. Zhang and Farber [32] showed 1.7 and $1.2 \log \mathrm{cfu} / \mathrm{g}$ reduction of $L$. monocytogenes on lettuce and cabbage treated with $200 \mathrm{ppm}$ of chlorine, respectively. Similarly, conventional fresh cut cilantro production uses chlorinated water at $100 \mathrm{mg} / \mathrm{L}$ to decontaminate cilantro leaves [33]. Wei et al. [34] reported that chlorinated water up to $200 \mathrm{ppm}$ is applied to reduce microbial contamination in produce processing lines. Despite chlorine's antimicrobial activity and low cost, the ever-increasing adverse effects of chlorine by-products have raised concerns in the food industry [33]. Furthermore, chlorine can lead to the formation of potentially carcinogenic and teratogenic trihalomethanes and haloacetic acids [35]. The results of our study indicate that $40 \mathrm{ppm}$ copper with $0.2 \%$ lactic acid in the presence of Tween 80 was significantly more effective $(P<0.05)$ in removing pathogenic bacteria from produce surfaces and could be a safer alternative. Slightly larger populations of $E$. coli O157:H7 were recovered from lettuce samples than tomatoes, which may be due to the differences in their surface structure. When Tween 80 was added to the treatment solution, a higher bacterial reduction was achieved on the surface of lettuce and tomatoes. Tween 80 is an ionic surfactant approved by the US Food and Drug Administration (FDA) and also generally recognized as a safe (GRAS) product. Addition of Tween 80 might have enhanced the lethality of copper and lactic acid solution by increasing the surface contact of the solution with the microbes, thereby maximizing the release of pathogens from inoculated lettuce and tomato surfaces. Our results in Tables 1 and 2 show $5 \log$ reduction in bacterial population that could be achieved with a combination of $40 \mathrm{ppm}$ copper and $0.2 \%$ lactic acid. This indicates that the combination of $40 \mathrm{ppm}$ copper and $0.2 \%$ lactic acid produced a significant reduction in E. coli $\mathrm{O} 157: \mathrm{H} 7$ in laboratory media to achieve a $5 \mathrm{log}$ reduction recommended by Food and Drug Administration [36]. Therefore, results of this study suggest that further research should explore the antimicrobial effect of copper in combination with lactic acid and other natural ingredients to achieve a minimum $5 \log$ reduction of bacterial population on the surface of fresh produce as well.

Many studies in the past have reported that various antimicrobial agents have altered the morphology of bacterial cells. Transmission electron microscopy (TEM) has shown that E. coli O157:H7 cells exposed to lactoferrin and lysozyme become enlarged and hypodense, indicating bacterial killing through osmotic damage [37]. In another study observed by TEM, bacteria treated with essential oils (Eos) showed formation of blebs, coagulation of cytoplasmic constituents, damaged cell structure, and were devoid of cytoplasmic material [38]. Similarly, SEM study of bacterial cells showed damage to the outer membrane and morphological changes of the cells when treated with eicosapentaenoic acid (EPA) and potassium salt of conjugated linoleic acid (CLA-K) $[39,40]$. Bacterial cells exposed to carvacrol and thymol showed the disintegration of outer membrane of E.coli O157:H7 and Salmonella Typhimurium. Disruption of the cell wall with roughness and lack of cytoplasm have been reported in Listeria monocytogenes when treated with thyme Eos [41]. Turgis et al. [42] showed physiological and morphological changes observed by electronic microscopy in $E$. coli O157:H7 and S. typhi caused by mustard EO, suggesting permeability of bacterial cells. The SEM, TEM, and Raman spectroscopy images indicate that zinc oxide nanoparticles may damage the bacterial cell membrane resulting in loss of intracellular components and eventually the death of cells [43]. In our current study, the morphological changes in $E$. coli O157:H7 caused by the action of copper and lactic acid are somehow similar to the observations made by previous studies [39-42]. The study of bacterial populations in laboratory medium did not show any effect of copper alone against E. coli O157:H7. However, the SEM study showed that copper alone can alter the cell morphology, and this could be considered as the initial stage of inhibition that may lead to the ultimate death of cells. Significant reduction $(P \leq$ 0.001) of cell size with combination treatment was probably due to the acidic permeability effect on the cell membrane. This effect on permeability could have further enhanced the antimicrobial efficacy of copper against bacterial cells.

The molecular mechanism by which copper and lactic acid affect antimicrobial activity is not well understood. Various authors have hypothesized that organic acids may damage the outer or cytoplasm cell membrane or denature proteins and DNA [44, 45]. Alakomi et al. [25] reported that the increase of permeability of bacteria membranes may potentiate the effect of other antimicrobial agents as shown with lactic acid and sodium laurylsulphate. Microorganisms including bacteria require copper at low concentrations as essential micronutrients, but, at high concentrations, copper can cause inhibition of cell growth or even death of the cells [11]. Helander and Mattila-Sandholm [46] found that an increase in cell wall and plasma membrane permeability 
can sensitize bacteria to an antimicrobial agent that alone is unable to penetrate into deeper bacterial targets. Therefore, one possible explanation of cell death could be that it is due to the changes of membrane permeability caused by the use of acid. It is possible that lactic acid may have permeabilized the cell membrane, allowing copper ions into the bacterial cells and thus producing a toxic effect. However, our SEM study does not show any type of inner cell membrane damage or denaturation of protein. We only observed differences in cell's shape and size. This finding suggests that further research inside the microorganism cell could provide additional knowledge about the extent of damage and the mode of action of copper and lactic acid against E. coli O157:H7. Transmission electron microscopy (TEM) can be used to observe bacterial ultrastructural alterations in detail. Furthermore, we believe that this study represents the first published work to demonstrate the antimicrobial activity of a copper in combination with lactic acid solution as a sanitizing agent. Copper in combination with lactic acid may produce a synergy that reduces the number of pathogenic microorganisms, including E. coli O157:H7, on the surfaces of lettuce and tomatoes. This solution could be a potential decontaminant for fresh produce. In conclusion, our study in laboratory medium and SEM has shown that copper in combination with lactic acid possesses antimicrobial activity against Gram-negative bacteria such as E. coli O157:H7. The growth inhibition confirmed by measuring bacterial growth and morphological changes in cell size observed from SEM images indicates the potential use of copper and lactic acid against E. coli O157:H7. Therefore, copper in combination with lactic acid could be potentially considered to be an effective antibacterial agent for enhancing agricultural and food safety.

\section{Acknowledgments}

This project was supported by the USDA National Institute of Food and Agriculture, Hatch Project number NC.X-2345-09-170-1 in the Agricultural Research Program at North Carolina Agricultural and Technical State University. The authors would like to express their gratitude to Dr. K. J. Grubar of the Agricultural Research Program at North Carolina A\&T State University for his review and comments on this paper. Partial funding for this work was provided by the National Center of Food Protection and Defense (NCFPD).

\section{References}

[1] S. Sivapalasingam, C. Friedman, L. Cohen, and R. Tauxe, "Fresh produce: a growing cause of outbreaks of foodborne illness in the United States, 1973 through 1997," Journal of Food Protection, vol. 67, no. 10, pp. 2342-2353, 2004.

[2] L. Velázquez, N. Barbini, M. Escudero, C. Estrada, and A. Guzmán, "Evaluation of chlorine, benzalkonium chloride and lactic acid as sanitizers for reducing Escherichia coli O157:H7 and Yersinia enterocolitica on fresh vegetables," Food Control, vol. 20, no. 3, pp. 262-268, 2009.
[3] F. López-Gálvez, A. Allende, M. Selma, and M. Gil, "Prevention of Escherichia coli cross-contamination by different commercial sanitizers during washing of fresh-cut lettuce," International Journal of Food Microbiology, vol. 133, no. 1-2, pp. 167-171, 2009.

[4] S. Koseki and K. Itoh, "Prediction of microbial growth in fresh-cut vegetables treated with acidic electrolyzed water during storage under various temperature conditions," Journal of Food Protection, vol. 64, no. 12, pp. 1935-1942, 2001.

[5] C. Park, Y. Hung, M. Doyle, G. Ezeike, and C. Kim, "Pathogen reduction and quality of lettuce treated with electrolyzed oxidizing and acidified chlorinated water," Journal of Food Science, vol. 66, no. 9, pp. 1368-1372, 2001.

[6] K. McWatters, M. Chinnan, S. Walker, M. Doyle, and C. Lin, "Consumer acceptance of fresh-cut iceberg lettuce treated with $2 \%$ hydrogen peroxide and mild heat," Journal of Food Protection, vol. 65, no. 8, pp. 1221-1226, 2002.

[7] S. D. Richardson, A. D. Thruston Jr., T. V. Caughran, T. W. Collette, K. S. Patterson, and B. W. Lykins Jr., "Chemical by-products of chlorine and alternative disinfectants," Food Technology, vol. 52, no. 4, pp. 58-61, 1998.

[8] S. Rodgers, J. Cash, M. Siddiq, and E. T. Ryser, "A comparison of different chemical sanitizers for inactivating Escherichia coli O157:H7 and Listeria monocytogenes in solution and on apples, lettuce, strawberries, and cantaloupe," Journal of Food Protection, vol. 67, no. 4, pp. 721-731, 2004.

[9] G. Borkow and J. Gabbay, "Copper as a biocidal tool," Current Medicinal Chemistry, vol. 12, no. 18, pp. 2163-2175, 2005.

[10] J. Trevors and C. Cotter, "Copper toxicity and uptake in microorganisms," Journal of Industrial Microbiology, vol. 6, no. 2, pp. 77-84, 1990.

[11] G. Faúndez, M. Troncoso, P. Navarrete, and G. Figueroa, "Antimicrobial activity of copper surfaces against suspensions of Salmonella enterica and Campylobacter jejuni," BMC Microbiology, vol. 4, article 1, pp. 1-7, 2004.

[12] S. A. Ibrahim, H. Yang, and C. W. Seo, "Antimicrobial activity of lactic acid and copper on growth of Salmonella and Escherichia coli O157:H7 in laboratory medium and carrot juice," Food Chemistry, vol. 109, no. 1, pp. 137-143, 2008.

[13] S. Rodgers and E. Ryser, "Reduction of microbial pathogens during apple cider production using sodium hypochlorite, copper ion, and sonication," Journal of Food Protection, vol. 67, no. 4, pp. 766-771, 2004.

[14] R. L. Mato Rodriguez and T. Alatossava, "Effects of copper on germination, growth and sporulation of Clostridium tyrobutyricum," Food Microbiology, vol. 27, no. 3, pp. 434-437, 2010.

[15] B. Ray and W. E. Sandine, "Acetic, propionic, and lactic acids of starter culture bacteria as biopreservatives," in Food Biopreservatives of Microbial Origin, B. Ray and M. Daeschel, Eds., CRC Press, Boca Raton, Fla, USA, 1992.

[16] J. S. Dickson and M. E. Anderson, "Microbiological decontamination of food animal carcasses by washing and sanitizing systems: a review," Journal of Food protection, vol. 55, pp. 133140, 1992.

[17] G. G. Greer and B. D. Dilts, "Lactic acid inhibition of the growth of spoilage bacteria and cold tolerant pathogens on pork," International Journal of Food Microbiology, vol. 25, no. 2, pp. 141-151, 1995.

[18] P. van Netten, J. Huis In't Veld, and D. A. Mossel, “An in-vitro meat model for the immediate bactericidal effect of lactic acid decontamination on meat surfaces," The Journal of Applied Bacteriology, vol. 76, no. 1, pp. 49-54, 1994. 
[19] P. Van Netten, D. A. Mossel, and J. Huis In't Veld, "Lactic acid decontamination of fresh pork carcasses: a pilot plant study," International Journal of Food Microbiology, vol. 25, no. 1, pp. 1-9, 1995.

[20] J. Beal, S. Niven, A. Campbell, and P. Brooks, "The effect of copper on the death rate of Salmonella typhimurium DT104: 30 in food substrates acidified with organic acids," Letters in Applied Microbiology, vol. 38, no. 1, pp. 8-12, 2004.

[21] M. Al-Holy, L. Castro, and H. Al-Qadiri, "Inactivation of cronobacter spp. (Enterobacter sakazakii) in infant formula using lactic acid, copper sulfate and monolaurin," Letters in Applied Microbiology, vol. 50, no. 3, pp. 246-251, 2010.

[22] S. Brul and P. Coote, "Preservative agents in foods: mode of action and microbial resistance mechanisms," International Journal of Food Microbiology, vol. 50, no. 1-2, pp. 1-17, 1999.

[23] D. H. Nies, "Microbial heavy-metal resistance," Applied Microbiology and Biotechnology, vol. 51, no. 6, pp. 730-750, 1999.

[24] Y. Han, R. Linton, S. Nielsen, and P. Nelson, "Inactivation of Escherichia coli O157:H7 on surface-uninjured and -injured green pepper (Capsicum annuum L.) by chlorine dioxide gas as demonstrated by confocal laser scanning microscopy," Food Microbiology, vol. 17, no. 6, pp. 643-655, 2000.

[25] H. L. Alakomi, E. Skyttä, M. Saarela, T. Mattila-Sandholm, K. Latva-Kala, and I. M. Helander, "Lactic acid permeabilizes gram-negative bacteria by disrupting the outer membrane," Applied and Environmental Microbiology, vol. 66, no. 5, pp. 2001-2005, 2000.

[26] M. Lang, L. Harris, and L. Beuchat, "Evaluation of inoculation method and inoculum drying time for their effects on survival and efficiency of recovery of Escherichia coli O157: H7, Salmonella, and Listeria monocytogenes inoculated on the surface of tomatoes," Journal of Food Protection, vol. 67, no. 4, pp. 732-741, 2004.

[27] D. Conner and J. Kotrola, "Growth and survival of Escherichia coli O157: $\mathrm{H} 7$ under acidic conditions," Applied and Environmental Microbiology, vol. 61, no. 1, pp. 382-385, 1995.

[28] Y. Han and R. H. Linton, "Fate of Escherichia coli O157: H7 and Listeria monocytogenes in strawberry juice and acidified media at different $\mathrm{pH}$ values and temperatures," Journal of Food Protection, vol. 67, no. 11, pp. 2443-2449, 2004.

[29] U. M. Abdul-Raouf, L. R. Beuchat, and M. S. Ammar, "Survival and growth of Escherichia coli O157:H7 in ground, roasted beef as affected by $\mathrm{pH}$, acidulants, and temperature," Applied and Environmental Microbiology, vol. 59, no. 8, pp. 2364-2368, 1993.

[30] C. Lin, S. Moon, M. Doyle, and K. McWatters, "Inactivation of Escherichia coli O157:H7, Salmonella enterica serotype Enteritidis, and Listeria monocytogenes on lettuce by hydrogen peroxide and lactic acid and by hydrogen peroxide with mild heat," Journal of Food Protection, vol. 65, no. 8, pp. 1215-1220, 2002.

[31] D. Ukuku, V. Pilizota, and G. Sapers, "Influence of washing treatment on native microflora and Escherichia coli population of inoculated cantaloupes," Journal of Food Safety, vol. 21, no. 1, pp. 31-47, 2001.

[32] S. Zhang and J. M. Farber, "The effects of various disinfectants against Listeria monocytogenes on fresh-cut vegetables," Food Microbiology, vol. 13, no. 4, pp. 311-321, 1996.

[33] H. Wang, H. Feng, and Y. Luo, "Microbial reduction and storage quality of fresh-cut cilantro washed with acidic electrolyzed water and aqueous ozone," Food Research International, vol. 37, no. 10, pp. 949-956, 2004.
[34] C. Wei, D. Cook, and J. Kirk, "Use of chlorine compounds in the food industry," Food Technology, vol. 39, no. 1, pp. 107115, 1985.

[35] A. Stevens, "Reaction products of chlorine dioxide," Environmental Health Perspectives, vol. 46, pp. 101-110, 1982.

[36] FDA (Food and Drug Administration), "Hazard Analysis and Critical Control Point (HACCP); procedures for the safe and sanitary processing and importing of juice; food labeling: warning notice statements; labeling of juice products; final rules," Federal Register, vol. 63, pp. 37029-37056, 1998.

[37] R. T. Ellison and T. J. Giehl, "Killing of gram-negative bacteria by lactoferrin and lysozyme," Journal of Clinical Investigation, vol. 88, no. 4, pp. 1080-1091, 1991.

[38] R. Becerril, R. Gómez-Lus, P. Goñi, P. López, and C. Nerín, "Combination of analytical and microbiological techniques to study the antimicrobial activity of a new active food packaging containing cinnamon or oregano against E. coli and S. aureus," Analytical and Bioanalytical Chemistry, vol. 388, no. 5-6, pp. 1003-1011, 2007.

[39] J. Byeon, H. Song, T. Oh et al., "Growth inhibition of foodborne and pathogenic bacteria by conjugated linoleic acid," Journal of Agricultural and Food Chemistry, vol. 57, no. 8, pp. 3164-3172, 2009.

[40] S. Y. Shin, V. K. Bajpai, H. R. Kim, and C. Kang, "Antibacterial activity of eicosapentaenoic acid (EPA) against foodborne and food spoilage microorganisms," LWT-Food Science and Technology, vol. 40, no. 9, pp. 1515-1519, 2007.

[41] K. Fisher and C. Phillips, "Potential antimicrobial uses of essential oils in food: is citrus the answer?" Trends in Food Science and Technology, vol. 19, no. 3, pp. 156-164, 2008.

[42] M. Turgis, J. Han, S. Caillet, and M. Lacroix, "Antimicrobial activity of mustard essential oil against Escherichia coli O157:H7 and Salmonella typhi," Food Control, vol. 20, no. 12, pp. 1073-1079, 2009.

[43] Y. Liu, L. He, H. Mustapha, H. Li, Z. Q. Hu, and M. Lin, "Antibacterial activities of zinc oxide nanoparticles against Escherichia coli O157:H7," Journal of Applied Microbiology, vol. 107, no. 4, pp. 1193-1201, 2009.

[44] J. Delves-Broughton, "The use of EDTA to enhance the efficacy of nisin towards Gram-negative bacteria," International Biodeterioration \& Biodegradation, vol. 32, no. 1-3, pp. 87-97, 1993.

[45] S. C. Ricke, "Perspectives on the use of organic acids and short chain fatty acids as antimicrobials," Poultry Science, vol. 82, no. 4, pp. 632-639, 2003.

[46] I. M. Helander and T. Mattila-Sandholm, "Fluorometric assessment of Gram-negative bacterial permeabilization," Journal of Applied Microbiology, vol. 88, no. 2, pp. 213-219, 2000. 


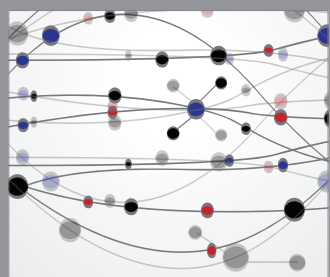

The Scientific World Journal
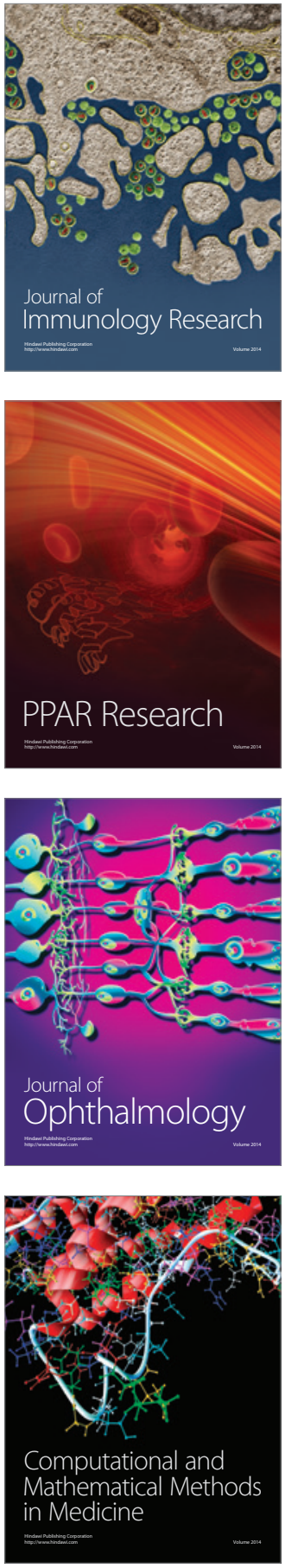

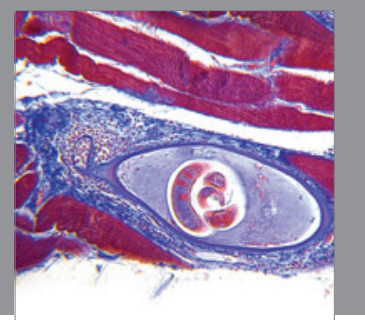

Gastroenterology

Research and Practice
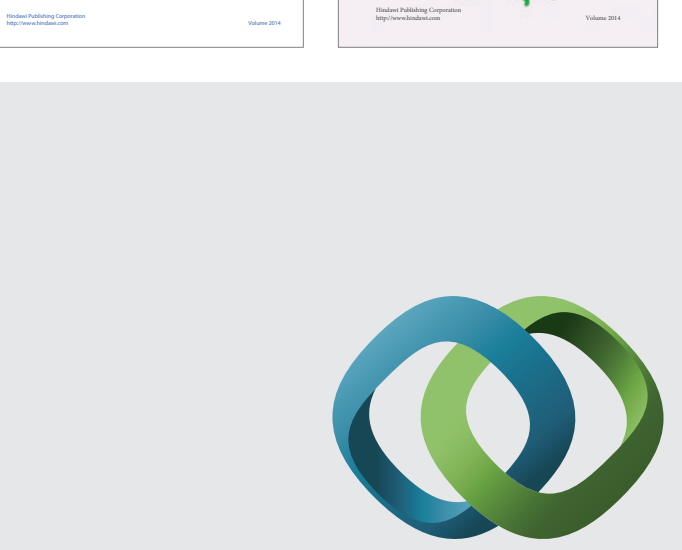

\section{Hindawi}

Submit your manuscripts at

http://www.hindawi.com
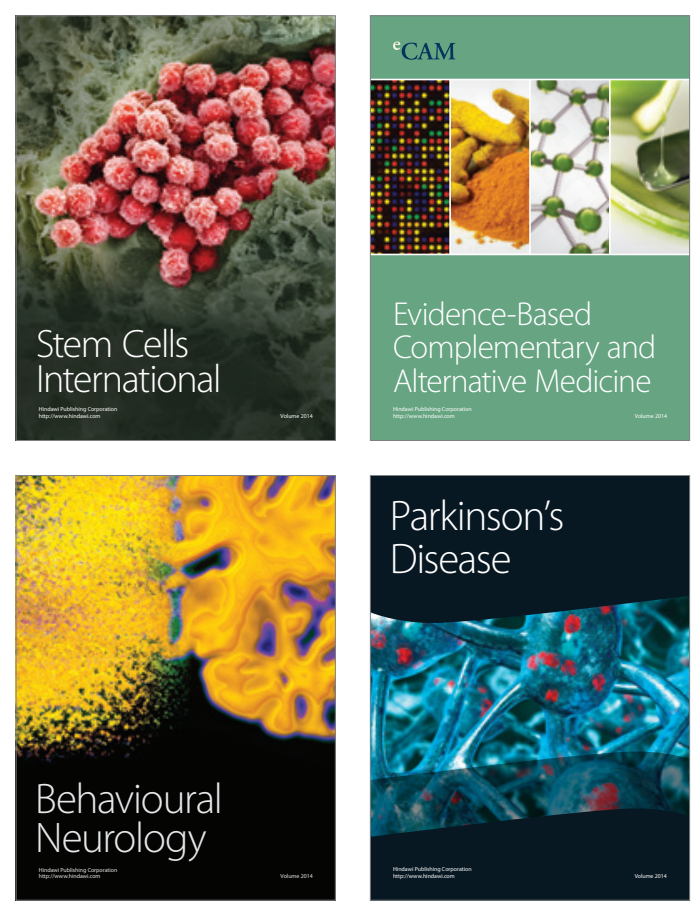

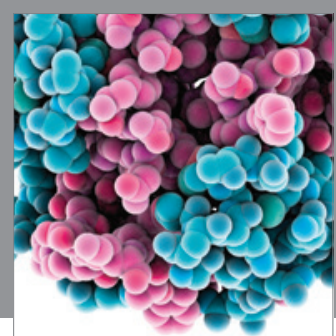

Journal of
Diabetes Research

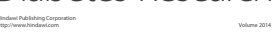

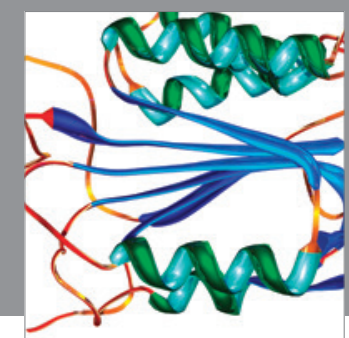

Disease Markers
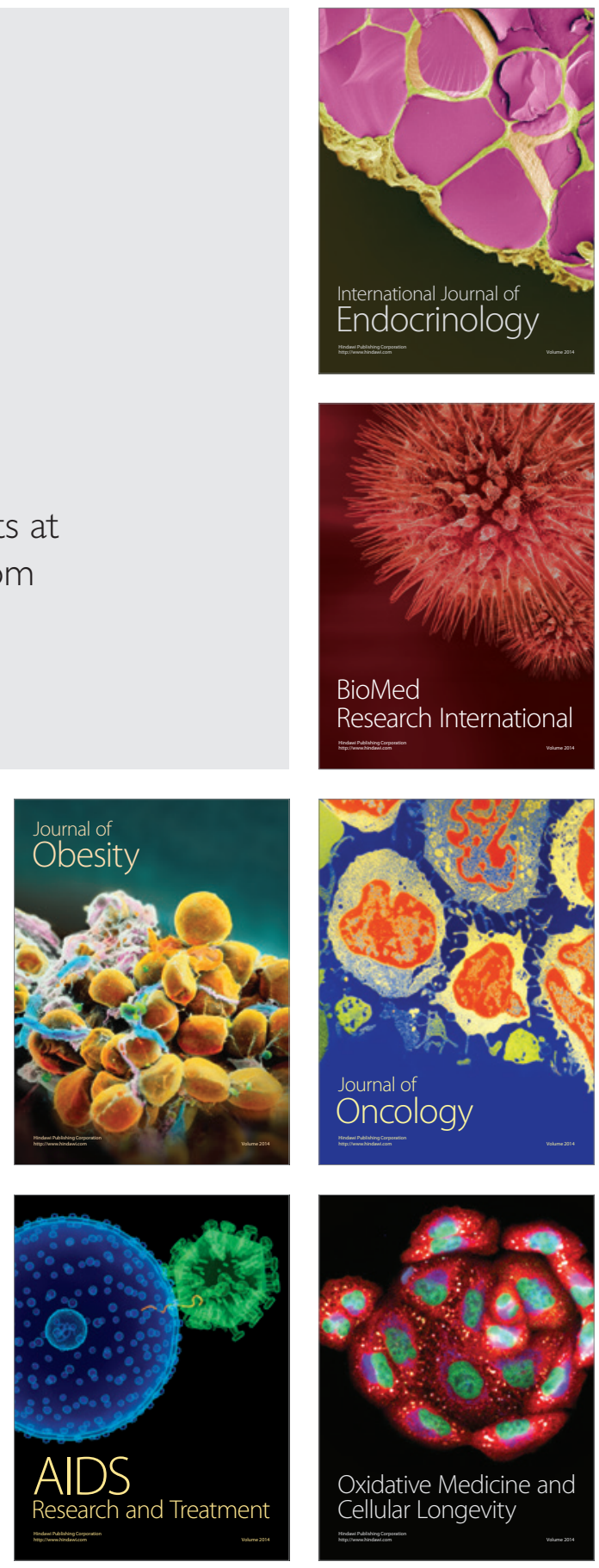